\title{
Quality of Imported Beef in Indonesia
}

\author{
Amam $^{1}$ and Haryono ${ }^{2}$ \\ Animal Husbandry Study Program, Faculty of Agriculture, University of Jember \\ Jl. Diponegoro, Kabupaten Bondowoso, Provinsi Jawa Timur 68251, Indonesia \\ ${ }^{2}$ Feedlot Company Supervisor, Indonesia \\ Jl. Nyimas Endang Geulis, Kabupaten Cirebon, Provinsi Jawa Barat 45165, Indonesia \\ Corresponding Author : amam.faperta@unej.ac.id \\ 081333666040
}

\begin{abstract}
Imported beef cattle are cattle (not breeds) imported from abroad to Indonesia, which have superior characteristics to be kept for a certain period to produce meat. The purpose of this research is to explore the quality of imported beef cattle entering Indonesia. The object of the research is beef cattle Breed Brahman Cross, Heifers type as many as 331 heads imported from Australia. The variables observed were Arrival weight (AW), Reweigh (RW), Selling Weight (SW), Weight Difference (WD), Fattening Duration (FD), and Average Daily Gain (ADG). Data analysis used Descriptives Analysis, Bivariate Correlations, and Linear Regression methods with IBM SPSS Statistics tools. The results showed that the lowest AW was $227 \mathrm{~kg}$ and the highest was $480 \mathrm{~kg}$; the average weight of the RW results is $354.43 \mathrm{~kg}$; The lowest SW was $361 \mathrm{~kg}$ and the highest was $619 \mathrm{~kg}$ with an average SW of $481.34 \mathrm{~kg}$; The lowest FD is 70 days and the highest is 109 days; The lowest ADG is $0.62 \mathrm{~kg}$ and the highest is $2.43 \mathrm{~kg}$ with an average ADG of $1.34 \mathrm{~kg}$. This study concludes that the Selling Weight (SW) of imported beef cattle Breed Brahman Cross-type Heifers is positively and significantly affected by the arrival weight (AW) of $44.6 \%$, Re-weighing (RW) of 52.6\%, weight difference (DW) of 18\%, and Average Daily Gain (ADG) of 38.3\%.
\end{abstract}

Keywords: ADG, Brahman Cross, Heifers, beef cattle fattening, cattle imported from Australia

\section{INTRODUCTION}

Provisions for imported beef in Indonesia have been regulated by the Regulation of the Minister of Agriculture of the Republic of Indonesia Number 108/ Permentan /PD.410 /09/2014 concerning on importation of breeding cattle, breeding cattle, and ready-to-beef into the territory of the Republic of Indonesia. Minister of Agriculture Number 108/2014 states that beef cattle are non-breeding cattle that have superior characteristics to be kept for a certain period for meat production.

Indonesia imports significant amount of beef from Australia. The procedure for importing beef based on the PPID (Information and Documentation Management Officer) document is as follows: a) service users or their proxies report animal import plans at least 2 (two) days prior to arrival by filling in the Application for Animal Quarantine Inspection) KH-1 via online/manual PPK; b) quarantine officers check the fulfillment of the required documents (completeness, correctness, and validity of documents).

The next procedure is c) quarantine officers carry out a physical examination on the transportation means which includes clinical examination, and conformity of the contents of the document with the physical condition; d) the quarantine officer asks for information on animal mutation during transportation to the person in charge of the means of transportation, and the result is recorded in the Cargo Manifest of Animal and Animal Product/KH-3.

The import of cow based on the PPID Document consists of 5 (five) requirements, namely: 1) Import Approval Letter from the Ministry of Trade of the Republic of Indonesia; 2) Health Certificate issued by the authorized official in the Country of Origin (Australia) and other countries (if the transportation means transits other countries before entering Indonesia); 3) through a designated entry point; 4 ) reported and submitted to the quarantine officer at the entry point; and 5) Animal Quarantine Agency (IKH) is available for quarantine action.

The import policy is carried out in order to support the shortage of domestic meat production (Jiuhardi, 2016). Rusastra (2014) states that there are 3 (three) aspects discussed related to import policy, namely economic competitiveness and cattle business, market structure and beef price formation, and marketing efficiency of local cattle versus imported cattle. 
Danasari et al (2020) stated that a decrease in beef imports could reduce the local cow population, while an increase in beef imports could increase the local cow population. This shows that the import of beef to meet the national meat needs seems unavoidable for the Indonesian people.

The purpose of this study is to examine the quality of imported beef entering Indonesia. The beef are imported from Australia by a feedlot company in Indonesia. The novelty of this research is that it can explore the quality and performance of beef cattle from Brahman Cross heifers imported from Australia for fattening purposes which are kept for a certain period for meat production.

\section{MATERIALS AND METHODS}

The study was conducted in cage which consisted of 331 heads of Breed Brahman Cross breed heifers imported from Australia on March
9, 2017 with the aim of being kept for a certain period for producing meat. The feedlot beef importing company is one of the feedlot companies in Indonesia. The duration of maintenance ranges from 70-109 days. The variables observed were arrival weight (AW), reweigh (RW), selling weight (SW), weight difference (WD), fattening duration (FD), and average daily gain (ADG). Data analysis used Descriptives Analysis, Bivariate Correlations, and Linear Regression methods with IBM SPSS Statistics tools.

\section{RESULTS AND DISCUSSION}

\section{Imported Cattle Profile}

Descriptive analysis on arrival weight $(\mathrm{AW})$, reweigh (RW), selling weight $(\mathrm{SW})$, weight difference (WD), fattening duration (FD), and average daily gain (ADG) are described in Table 1.

Tabel 1. Descriptive analysis results

\begin{tabular}{lcccrr}
\hline \multicolumn{1}{c}{ Variable } & N & Min. & Max. & Mean & Std. Deviasi \\
\hline Arrival weight (AW) & 331 & 227 & 480 & 331.16 & 37.63 \\
Reweigh (RW) & 331 & 230 & 492 & 354.43 & 36.50 \\
Selling weight (SW) & 331 & 361 & 619 & 481.34 & 38.23 \\
Weight difference (WD) & 331 & 60 & 267 & 150.18 & 30.93 \\
Fattening duration (FD) & 331 & 70 & 109 & 96.40 & 12.07 \\
Average daily gain (ADG) & 331 & 0.62 & 2.43 & 1.34 & 0.28 \\
\hline
\end{tabular}

Sumber: Output IBM SPSS Statistics (2020)

Imported beef cattle are imported from Australia with the aim of meeting the national meat needs. Cattle imports are also useful for reducing the number of cattle slaughter in Indonesia which has an impact on the population of beef cattle. The population of beef cattle is still dominated by smallholder farms with household scales that are not yet oriented to the livestock business (Setiawan et al., 2014; Sunarto et al., 2015; Harsita and Amam, 2021). Therefor the main problem in the livestock business is a fundamental risk for community breeders (Pradiptya and Amam, 2019); because the implications of the three pillars of livestock business are still low, namely breeding, feeding, and management.

The limited resources of breeders are the main obstacle to the development of smallholder beef cattle businesses (Amam and Harsita, 2021) because resources have an important role in the development of livestock business (Amam et al., 2019). Amam et al. (2021) state that livestock business resources consist of financial resources, technological resources, physical resources, economic resources, environment, and social. The lower the access of farmers to resources, the smaller the potential for developing livestock business. Such conditions have an impact on imports of beef cattle from abroad (Amam and Haryono, 2021), thus affecting sustainable livestock development (Setyawan and Amam, 2021).

Imports of beef beef cattle from abroad can reduce the number of local cattle slaughter so that Indonesia can maintain its domestic beef cattle population. The import of beef cattle is one of the efforts to meet the national meat demand considering that the daily body weight (ADG) growth of the Brahman Cross Heifers breed can reach $2.43 \mathrm{~kg}$ for the highest size, while the lowest is $0.62 \mathrm{~kg}$. Such conditions are of course also supported by various livestock business resources including technological resources to improve the 
quality of animal feed (Soetriono and Amam, 2020).

Feeding is carried out by zig-zag feeding method, alternating between concentrate and straw. Forty (40\%) of the concentrate is given in the morning at 08.00 WIB and $60 \%$ in the afternoon at 13.00 WIB. The average concentration was determined based on the calculation of $2.65 \%$ DM (dry matter) per BW (bodyweight) and the maximum level was $2.85 \%$ $\mathrm{DM}$ per $\mathrm{BW}$. The concentrate was given gradually to avoid acidosis in cattle. Concentrate is given in the first week by $20 \%$, in the second week by $40 \%$, and in the third week by $60 \%$, and so on. Straw was given in the morning at 10.00 WIB and at 15.00 WIB, while at night if the beef is empty it can be refilled with sufficient straw.

The initial phase of cattle arrival (AW) generally occurs in weight loss, so that during reweighing (RW) there is a difference in weight. This condition is influenced by the stress of cattle during transportation. The further the distance traveled, the higher the weight loss of the cow. The decrease in RW weight can also be caused by the condition of the cow's body weight. The heavier the cow's body weight, the higher the rate of weight loss will be. Monitoring of bodyweight of cattle is carried out periodically, ie every 30 days by sampling as much as $12 \%$ of the total population in the pen. The base of the cage (litter) used sawdust which is routinely cleaned and replaced every 14 days.

\section{Relationship between variables}

The variables in this study are interrelated to obtain various findings in order to explore the quality of imported beef cattle. The relationship between variables is described in Table 2.

Tabel 2. Correlation analysis results

\begin{tabular}{|c|c|c|}
\hline Variable & Pearson Correlation & Sig. (2-tailed) \\
\hline $\mathrm{AW} ; \mathrm{RW}$ & $1 ; 0.937 * *$ & 0.000 \\
\hline $\mathrm{AW} ; \mathrm{SW}$ & $1 ; 0.668 * *$ & 0.000 \\
\hline AW ; WD & $1:-0.391 * *$ & 0.000 \\
\hline AW ; FD & $1 ;-0.688 * *$ & 0.000 \\
\hline AW ; ADG & $1 ;-0.040$ & 0.468 \\
\hline $\mathrm{SW} ; \mathrm{RW}$ & $1 ; 0.725 * *$ & 0.000 \\
\hline SW ; WD & $1 ; 0.424 * *$ & 0.000 \\
\hline $\mathrm{SW} ; \mathrm{FD}$ & $1 ;-0.319 * *$ & 0.000 \\
\hline $\mathrm{SW} ; \mathrm{ADG}$ & $1 ; 0.619 * *$ & 0.000 \\
\hline $\mathrm{FD} ; \mathrm{RW}$ & $1 ;-0.606^{* *}$ & 0.000 \\
\hline FD ; WD & $1 ; 0.442 * *$ & 0.000 \\
\hline $\mathrm{FD} ; \mathrm{ADG}$ & $1 ;-0.106$ & 0.055 \\
\hline
\end{tabular}

Description: ** significance 1\% (0.01); Source: IBM SPSS Statistics Output Results (2020)

Imported beef cattle from Australia have arrival weights (AW) which is almost the same as when re-weighing (RW), this shows that the variables AW and RW have a close relationship, both are positively and significantly correlated. This condition indicates that there is no significant change in body weight when the cow arrives with the re-weighing time, meaning that there is no effect of excessive stress during transportation.

Arrivel weight (AW) is also directly proportional to Selling Weight (SW), there is a close relationship between the two. This shows a positive and significant correlation. This means that the higher the AW, the higher the SW. Arrival weight (AW) is inversely proportional to weight difference (WD), showing a negative and significant correlation. This shows that the higher the $\mathrm{AW}$, the lower the WD because the maintenance period or the length of time for fattening (FD) is getting shorter and the average daily body weight gain (ADG) is getting lower. 
Selling weight (SW) is directly proportional to re-weighing (RW) and weight difference (WD). This means that the selling weight of the cattle is directly proportional to the re-weighing and the difference in weight when the cattle arrive and when the cows are sold. The correlation is positive and significant. Selling Weight (SW) has a negative and significant correlation with the length of time for fattening (FD). This shows that the higher the BJ, the longer the DoF. This means that a longer maintenance time can affect the selling weight of live cattle.

The duration of fattening time (FD) was negatively and significantly correlated with reweighing $(\mathrm{RW})$. The longer the fattening period of beef cattle, the greater the re-weighing results. This is also supported by the correlation between FD and average daily gain (ADG). The relationship between the two is negative, but not significant. The length of time of rearing (FD) is directly and significantly proportional to the weight difference (WD), where WD is the weight of the cow when sold (SW) minus the weight of the cow when it arrives (AW).

\section{Inter-variable influence}

The variables in this study are interrelated to obtain various findings to explore the quality of imported beef cattle. The influence between variables is described in Table 2. The Daily Weight Gain or Average Daily Gain (ADG) of imported beef cattle Breed Brahman Cross heifers is positively and significantly affected by selling weight (SW) and weight difference (WD), respectively $38.3 \%$ and $66.3 \%$. Pitono et al. (2015) stated that the ADG of red Brahman Cross cattle was $1.03 \pm 0.07 \mathrm{~kg}$, while the white Brahman Cross was $1.08 \pm 0.15 \mathrm{~kg}$.

Tabel 3. Regression analysis results

\begin{tabular}{|c|c|c|c|c|c|c|c|}
\hline \multirow[t]{2}{*}{ Influence } & \multirow[t]{2}{*}{ Model } & \multicolumn{2}{|c|}{$\begin{array}{c}\text { Unstandardized } \\
\text { Coefisients }\end{array}$} & Std. Coef. & \multirow[t]{2}{*}{$\mathrm{t}$} & \multirow[t]{2}{*}{ Sig. } & \multirow[t]{2}{*}{$\mathrm{R}^{2}$} \\
\hline & & B & Std. Error & Beta & & & \\
\hline \multirow[t]{2}{*}{$\mathrm{ADG} \rightarrow \mathrm{WD}$} & Constants & 1.448 & 0.141 & & 10.268 & 0.000 & \\
\hline & WD & 0.000 & 0.000 & -0.040 & -0.727 & 0.468 & 0.002 \\
\hline \multirow[t]{2}{*}{$\mathrm{ADG} \rightarrow \mathrm{RW}$} & Constants & 1.190 & 0.155 & & 7.668 & 0.000 & \\
\hline & RW & 0.000 & 0.000 & 0.055 & 1.005 & 0.316 & 0.003 \\
\hline \multirow[t]{2}{*}{$\mathrm{ADG} \rightarrow \mathrm{SW}$} & Constants & -0.907 & 0.158 & & -5.739 & 0.000 & \\
\hline & SW & 0.005 & 0.000 & 0.619 & 14.302 & 0.000 & $0.383^{*}$ \\
\hline \multirow[t]{2}{*}{$\mathrm{ADG} \rightarrow \mathrm{WD}$} & Constants & 0.204 & 0.046 & & 4.440 & 0.000 & \\
\hline & WD & 0.008 & 0.000 & 0.814 & 25.421 & 0.000 & $0.663 *$ \\
\hline \multirow[t]{2}{*}{$\mathrm{ADG} \rightarrow \mathrm{FD}$} & Constants & 1.589 & 0.127 & & 12.472 & 0.000 & \\
\hline & FD & 0.003 & 0.001 & -0.106 & -1.927 & 0.055 & 0.011 \\
\hline \multirow[t]{2}{*}{$\mathrm{SW} \rightarrow \mathrm{AW}$} & Constants & 256.720 & 13.899 & & 18.471 & 0.000 & \\
\hline & AW & 0.678 & 0.042 & 0.668 & 16.265 & 0.000 & $0.446^{*}$ \\
\hline \multirow[t]{2}{*}{$\mathrm{SW} \rightarrow \mathrm{RW}$} & Constants & 212.063 & 14.160 & & 14.976 & 0.000 & \\
\hline & RW & 0.760 & 0.040 & 0.725 & 19.118 & 0.000 & $0.526^{*}$ \\
\hline \multirow[t]{2}{*}{$\mathrm{SW} \rightarrow \mathrm{WD}$} & Constants & 402.672 & 9.463 & & 42.550 & 0.000 & \\
\hline & WD & 0.524 & 0.062 & 0.424 & 8.487 & 0.000 & $0.180 *$ \\
\hline \multirow[t]{2}{*}{$\mathrm{SW} \rightarrow \mathrm{FD}$} & Constants & 578.785 & 16.069 & & 36.019 & 0.000 & \\
\hline & FD & -1.011 & 0.165 & -0.319 & -6.111 & 0.000 & $0.102 *$ \\
\hline \multirow[t]{2}{*}{$\mathrm{SW} \rightarrow \mathrm{ADG}$} & Constants & 371.100 & 7.884 & & 47.072 & 0.000 & \\
\hline & ADG & 81.925 & 5.728 & 0.619 & 14.302 & 0.000 & $0.383^{*}$ \\
\hline \multirow[t]{2}{*}{$\mathrm{FD} \rightarrow \mathrm{AW}$} & Constants & 169.530 & 4.280 & & 39.613 & 0.000 & \\
\hline & AW & -0.221 & 0.013 & -0.688 & -17.196 & 0.000 & $0.473^{*}$ \\
\hline \multirow[t]{2}{*}{$\mathrm{FD} \rightarrow \mathrm{RW}$} & Constants & 167.459 & 5.170 & & 32.392 & 0.000 & \\
\hline & RW & -0.200 & 0.015 & -0.606 & -13.817 & 0.000 & $0.367^{*}$ \\
\hline \multirow[t]{2}{*}{$\mathrm{FD} \rightarrow \mathrm{SW}$} & Constants & 144.954 & 7.969 & & 18.189 & 0.000 & \\
\hline & SW & -0.101 & 0.017 & -0.319 & -6.111 & 0.000 & $0.102 *$ \\
\hline \multirow[t]{2}{*}{$\mathrm{FD} \rightarrow \mathrm{WD}$} & Constants & 70.465 & 2.960 & & 23.805 & 0.000 & \\
\hline & WD & 0.173 & 0.019 & 0.442 & 8.947 & 0.000 & $0.196^{*}$ \\
\hline \multirow[t]{2}{*}{$\mathrm{FD} \rightarrow \mathrm{ADG}$} & Constants & 102.346 & 3.154 & & 32.453 & 0.000 & \\
\hline & $\mathrm{ADG}$ & -4.415 & 2.291 & -0.106 & -1.927 & 0.055 & 0.011 \\
\hline
\end{tabular}

Description: * 0.05 . significanc; Source: IBM SPSS Statistics Output Results (2020). 
Selling weight $(\mathrm{SW})$ of imported beef cattle of Breed Brahman Cross-type heifers is positively and significantly affected by arrival weight (AW) of $44.6 \%$, reweighing (RW) of $52.6 \%$, weight difference (WD) of $18.0 \%$, and average daily gain (ADG) of $38.3 \%$, but SW is negatively and significantly affected by the length of time maintenance (fattening) of $10.2 \%$. This shows that there is a negative effect of the length of time rearing (fattening) on the selling weight of cattle. Hikmawaty et al. (2018) state that body measurements that are very demanding in estimating body weight are chest circumference, shoulder height, and body length.

The duration of fattening (FD) of imported beef cattle of Brahman Cross-type heifers is positively and significantly affected by weight difference (WD) of $19.6 \%$, but FD is negatively and significantly affected by the arrival weight (AW) of $47.3 \%$, Reweigh (RW) of $36.7 \%$, Selling Weight (SW) of $10.2 \%$. Hamdani et al. (2018) stated that Brahman Cross cattle on smallholder farms had an average body weight $(271.12 \pm 26.03 \mathrm{~cm})$, chest circumference $(154.04 \pm 6.01 \mathrm{~cm})$, body length $(107.42 \pm 3,42$ $\mathrm{cm})$, and shoulder height $(124 \pm 2.23 \mathrm{~cm})$, while Brahman Cross cattle in commercial companies had an average body weight $(383.92 \pm 35.05 \mathrm{~kg})$, chest circumference $(175.9 \pm 4.27 \mathrm{~cm})$, body length $(111.1 \pm 6.99 \mathrm{~cm})$.

\section{CONCLUSION}

The quality of imported beef cattle of Brahman Cross-type heifers from Australia kept in feedlot companies has the lowest weight arrival in at $227 \mathrm{~kg}$ and the highest at $480 \mathrm{~kg}$; the average weight of the re-weighing is $354.43 \mathrm{~kg}$; the lowest selling weight is $361 \mathrm{~kg}$ and the highest is $619 \mathrm{~kg}$ with an average selling weight of $481.34 \mathrm{~kg}$; the shortest length of fattening time is 70 days and the longest is 109 days; The lowest daily weight gain (ADG) was $0.62 \mathrm{~kg}$ and the highest was $2.43 \mathrm{~kg}$ with an average ADG of $1.34 \mathrm{~kg}$. Selling Weight (SW) of imported beef cattle Brahman Cross-type Heifers is positively and significantly affected by arrival weight (AW) by $44.6 \%$, Re-weighing (RW) by $52.6 \%$, weight difference (WD) by $18 \%$, and Average Daily Gain (ADG) of 38.3\%.

\section{REFERENCES}

Amam, A., Z. Fanani, B. Hartono, and B.A. Nugroho. 2019. The power of resources in independent livestock farming business in Malang District, Indonesia. IOP
Conferences Series: Earth and Environmental Science. 372: 1-10. DOI: http://doi.org/10.1088/1755$\underline{1315 / 372 / 1 / 012055}$.

Amam, A. dan P. A. Harsita. 2021. Profil usaha peternakan sapi potong rakyat di Kabupaten Jember. Jami: Jurnal Ahli Muda Indonesia. $\quad 2$ (1): $1-12$. https://doi.org/10.46510/jami.v2i1.53.

Amam, A. dan H. Haryono. 2021. Pertambahan bobot badan sapi impor Brahman Cross heifers dan steers pada bobot kedatangan yang berbeda. Jurnal Ilmu Peternakan Terapan 4 (2): $104-109$. https://doi.org/10.25047/jipt.v4i2.2357.

Amam, A., H. B. Setyawan, M. W. Jadmiko, P. A. Harsita, S. Rusdiana, dan M. Luthfi. 2021. Pengaruh sumber daya manusia terhadap aksesibilitas sumber daya usaha ternak sapi potong rakyat. Jurnal Ilmu dan Teknologi Peternakan Tropis. 8 (1): 57-65. http://dx.doi.org/10.33772/jitro.v8i1.14118 ..

Danasari, I. D., Harianto, dan A. F. Falatehan. 2020. Dampak kebijakan impor ternak terhadap populasi sapi potong lokal di Indonesia. Jurnal Ekonomi Pertanian dan Agribisnis. 4 (2): 310-322. DOI: https://doi.org/10.21776/ub.jepa.2020.004. $\underline{02.9 .}$

Hamdani, M. D. I., A. Husni, M. T. Fajar, dan Sulastri. 2018. Perbandingan performa kuantitatif sapi Brahman Cross di peternakan rakyat dengan di perusahaan komersial pada umur 18-24 bulan. Jurnal Ilmu dan Teknologi Peternakan Tropis 5 (3): 25-30. DOI: http://dx.doi.org/10.33772/jitro.v5i3.4721.

Harsita, P. A. dan A. Amam. 2021. Gaduhan: Sistem kemitraan usaha peternakan sapi potong rakyat di Pulau Jawa. Jurnal Peternakan Sriwijaya 10 (1): 16-28. http://dx.doi.org/10.33230/JPS.10.1.2021. 13030.

Harsita, P. A. dan A. Amam. 2019. Permasalahan utama usaha ternak sapi potong di tingkat peternak dengan pendekatan Vilfredo Pareto Analysis. Seminar Nasional 
Teknologi Peternakan dan Veteriner. 241250.

DOI: http://dx.doi.org/10.14334/Pros.Semnas.T PV-2019-p.241-250.

Hikmawaty, Bellavista, A.T.B.A. Mahmud, dan A. Salam A. 2018. Korelasi bobot badan dan varabel-variabel ukuran tubuh sebagai dasar seleksi induk sapi Bali. Agrovita. 3 (1): 11-13. DOI: http://dx.doi.org/10.35329/agrovital.v3i1.2 $\underline{14}$.

Jiuhardi. 2016. Kajian tentang impor daging sapi di Indonesia. Forum Ekonomi. 17 (2): 75 91.

DOI: http://dx.doi.org/10.29264/jfor.v17i2.21.

Pitono, A. C., H. Nugroho, Kuswati, dan T. Susilawati. 2015. Performan sapi Brahman Cross Steer warna merah dan putih pada fase finisher. 1-9. https://fapet.ub.ac.id/wpcontent/uploads/2015/04/PERFORMANSAPI-BRAHMAN-CROSS-STEERWARNA-MERAH-DAN-PUTIH-PADAFASE-FINISHER.pdf.

Rusastra, I. W. 2014. Perdagangan ternak dan daging sapi: Rekonsiliasi kebijakan impor dan revitalisasi pemasaran domestik. Forum Penelitian Agro Ekonomi 32 (1): 59 71. DOI: http://dx.doi.10.21082/fae.v32n1.2014.59$\underline{71}$.

Setiawan, H. M., B. Hartono, dan H.D. Utami. 2014. Kontribusi pendapatan usaha ternak sapi potong terhadap pendapatan rumah tangga peternak.

$1-10$.

https://fapet.ub.ac.id/wp-

content/uploads/2014/06/JURNALKU.pdf.

Setiawan, H. B. dan A. Amam. 2021. Pembangunan peternakan berkelanjutan dalam perspektif standar kompetensi lulusan program studi sarjana peternakan di Indonesia. Jami: Jurnal Ahli Muda Indonesia 2 (1): 21-36. https://doi.org/10.46510/jami.v2i1.56.

Soetriono and A. Amam. 2020. The performance of institutional of dairy catlle farmers and their effect on financial, technologycal, and psysical resources. Jurnal Ilmu Ilmu $\begin{array}{lll}\text { Peternakan } 30 & \text { (2): 128-137. DOI: }\end{array}$ https://doi.org/10.21776/ub.jiip.2020.030.0 $\underline{2.05}$.

Sunarto, E., O. H. Nono, U. R. Lole, dan Y. L. Henuk. 2015. Kondisi ekonomi rumah tangga peternak penggemukan sapi potong pada peternakan rakyat di Kabupaten Kupang. Jurnal Peternakan Indonesia 18 (1): 21-28. https://doi.org/10.25077/jpi.18.1.21$\underline{28.2016 .}$.

Syaiful, F. L., Khasrad, dan S. Maulida, S. 2020. Identifikasi ukuran tubuh sapi Bali dan Simbal (Simmental-Bali) di Kecamatan Luhak Nan Dou Kabupaten Pesaman Barat. Jurnal Sain Peternakan Indonesia 12 (2): 219-226.

DOI: https://doi.org/10.31186/jspi.id.15.2.219$\underline{226 .}$. 